\title{
Proceeding Paper \\ Physicochemical Properties and REE Distribution of the Northwest and Central Greece Coal Deposits: A Review ${ }^{\dagger}$
}

\author{
Nikolaos Koukouzas ${ }^{1}$, Stavros Kalaitzidis ${ }^{2, *} \mathbb{C}$, Petros Koutsovitis ${ }^{2}{ }^{\mathbb{D}}$, Antonios Bouzinos ${ }^{2,3}$, Christos Karkalis ${ }^{1}$ \\ Pavlos Tyrologou ${ }^{1}$ (D) and Dimitris Karapanos ${ }^{1}$ \\ 1 Chemical Process \& Energy Resources Institute, Centre for Research \& Technology Hellas (CERTH), \\ 15125 Maroussi, Greece; koukouzas@certh.gr (N.K.); karkalis@certh.gr (C.K.); tyrologou@certh.gr (P.T.); \\ karapanos@certh.gr (D.K.) \\ 2 Section of Earth Materials, Department of Geology, University of Patras, 26504 Patras, Greece; \\ pkoutsovitis@upatras.gr (P.K.); antonios@measuredgroup.com.au (A.B.) \\ 3 Measured Group Pty Ltd., Brisbane, QLD 4000, Australia \\ * Correspondence: skalait@upatras.gr; Tel.: +30-026-109-9615 \\ + Presented at International Conference on Raw Materials and Circular Economy, Athens, Greece, \\ 5-9 September 2021.
}

check for updates

Citation: Koukouzas, N.; Kalaitzidis, S.; Koutsovitis, P.; Bouzinos, A.; Karkalis, C.; Tyrologou, P.;

Karapanos, D. Physicochemical Properties and REE Distribution of the Northwest and Central Greece Coal Deposits: A Review. Mater. Proc. 2021, 5, 103. https://doi.org/ $10.3390 /$ materproc2021005103

Academic Editor: Evangelos Tzamos

Published: 17 January 2022

Publisher's Note: MDPI stays neutral with regard to jurisdictional claims in published maps and institutional affiliations.

Copyright: (C) 2022 by the authors. Licensee MDPI, Basel, Switzerland. This article is an open access article distributed under the terms and conditions of the Creative Commons Attribution (CC BY) license (https:// creativecommons.org/licenses/by/ $4.0 /)$.
Abstract: This review presents a mineralogical and physicochemical comparison of coal seams located in the regions of Northwest and Central Greece. The comparison extends to the fly ash derivatives from the coal combustion for energy production, in the cases where data are available. Coal occurrences from Northwest Greece tend to exhibit higher content of rare earth elements (REE) compared to those of Central Greece. Moreover, fly ash products show similar trends in Light-REE compared to their coal parent rocks. The observed REE distribution seems to be correlated with the occurrence of specific minerals such as allanite, monazite, as well as with Fe-contents.

Keywords: lignite; fly ash; maceral; rank; REE

\section{Introduction}

In Greece, lignite combustion used to be the primary power generation process, satisfying over $30 \%$ of the national generation and corresponding to $19 \%$ of the Total Primary Energy Supply (TPES) during 2016. However, nowadays, and as following the EU policies intends to be a front-runner in diminishing the reliance on domestic lignite, the contribution of lignite-fired power plants in the energy sector is rapidly decreasing, although they still play a significant role in the stability of the electricity system [1].

Nevertheless, in this energy-transition phase, new opportunities that were overlooked in the past, as well as challenges, have arisen concerning the potential value of domestic lignite deposits, and their industrial wastes/derivatives. Among the various factors that contribute to any decision making processes regarding the prospect and/or exploitation of any raw material, knowing the properties of the raw material in question is the primary step.

In this context, this paper presents a synthetic review comparison of previously published in scientific journals, or partially published in technical research data reports on petrographical, mineralogical and physicochemical features from selected coal basins in Northwest and Central Greece. The study areas include the following basins: (1) Mesohellenic Trough, (2) Dimitras-Karperos-Grevena basin, (3) Kastoria basin, (4) Ptolemais basin, (5) Amyntaio basin, (6) Lavas-Servion basin and (7) Prosillio-Trigoniko basin from the Northwest region of Greece, and the Almyros basin in Central Greece (Figure 1a).

The aim is to discuss the similarities and differences between the aforementioned regions in terms of their essential properties, and to provide an initial record of the REE distribution when data are available. 


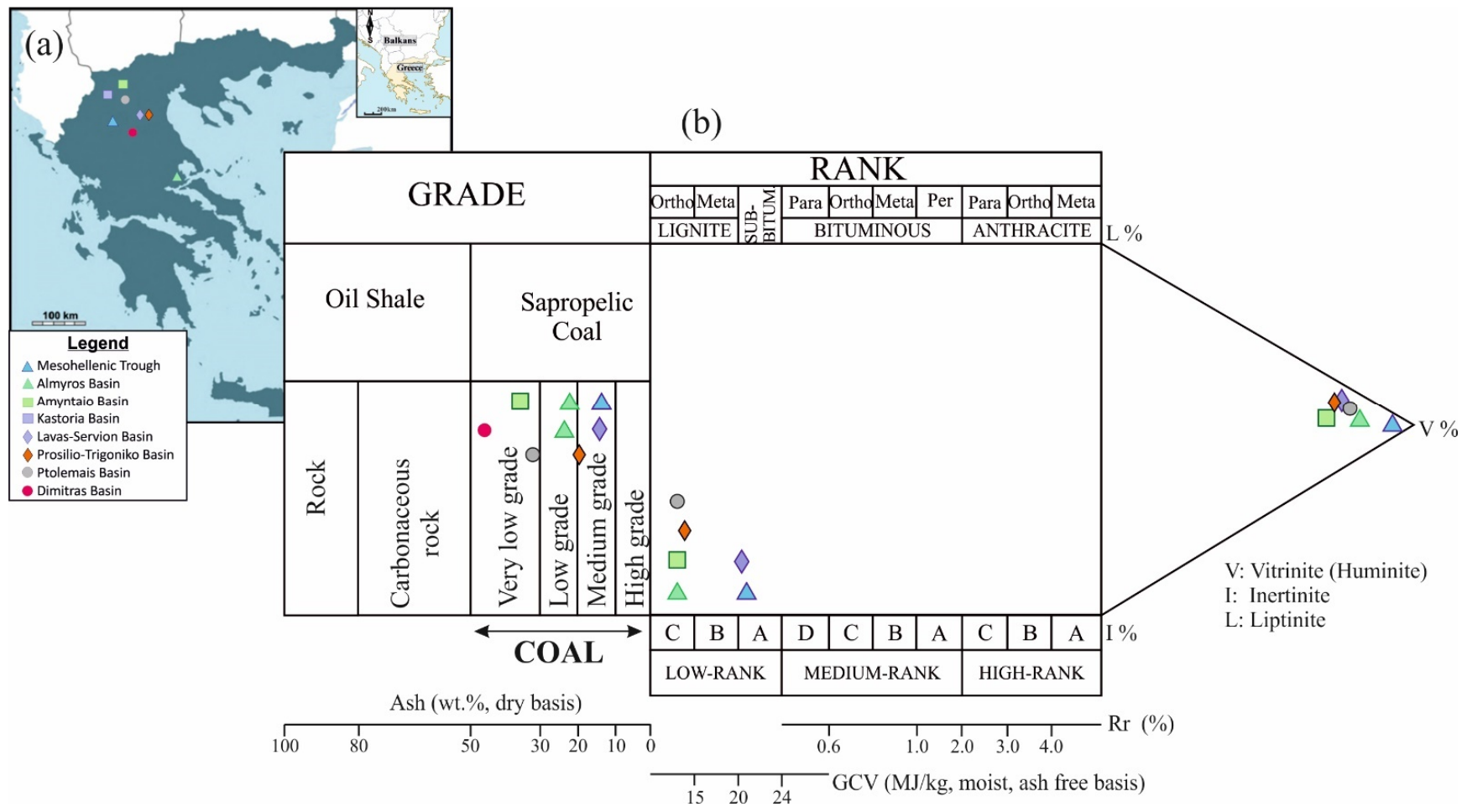

Figure 1. (a) Map of Greece indicating the studied coal basins; (b) ECE-UN classification of the reviewed coal basins [2].

\section{Geological Setting}

The lignite-bearing sequences investigated in this study were deposited in two main tectonic phases; the older one is related to the formation of the Mesohellenic Trough as a back-arc sedimentary basin that evolved during the Late-Oligocene to Miocene period [3-6] within the stratigraphic units of this basin, where thin coal layers or lenses were developed under deltaic and fluvial-lacustrine regimes. The second and main phase of coal formation in Greece is related to the post-Alpine extension phase (Late Miocene to Late Pliocene) that produced several intermontane basins in a NW-SE direction, occurring across the main axis of Mainland Greece (Figure 1a). These intermontane basins, from a North to South direction, include the Kastoria, Amyntaio-Ptolemais [7,8], Lavas-Servion, Prosilio-Trigoniko [9,10] and Dimitras basins, as well as the Almyros basin further to the SE, and host thick lignite seams [11], intercalating primarily with marls and clays, deposited mostly under lacustrine regimes and secondary under fluviatile ones.

\section{Methodology}

This review is based on an evaluation of data published in international journals, as well as in publicly accessible repository domains. Data were collated, evaluated, processed and presented in Harker (binary) diagrams, ternary diagrams, REE-chondrite normalized diagrams, and multi-trace primitive mantle element diagrams.

\section{Results and Discussion}

\subsection{Proximate, Ultimate Analysis and Coalification}

Regarding the proximate analysis data, the reported coals are mainly characterized by medium to high ash yields in their exploitable (proven and/or probable) reserves, with the coals of Tsotili in Mesohellenic Trough, Prosilio and Lava displaying average values $\leq$ $15 \mathrm{wt} \%$ (dry basis), whereas the rest display between $15-25 \mathrm{wt} \%(\mathrm{db})$, with the Amyntaio lignites being the most inferior (reaching even $40 \mathrm{wt} \%$, db) (Table 1, Figure 1b). 
The volatile matter parameter ranges from 25 to $40 \mathrm{wt} \%$ (dry ash free basis) in Almyros, Mesohellenic Trough, Prosilio and Lava to $>50 \mathrm{wt} \%$ in the Ptolemais basin. Subsequently, fixed carbon yields are above $40 \mathrm{wt} \%$ (dry ash free basis) in the Mesohellenic Trough, between 20-40 wt\% in Almyros, Ptolemais, Prosilio and Lava, and below 20 in Amyntaio. In terms of heating value, the highest values $(>5000 \mathrm{kcal} / \mathrm{kg})$ are recorded in coals from the Mesohellenic Trough and Lava, and the lowest $(1700 \mathrm{kcal} / \mathrm{kg})$ in Amyntaio. The features of the proximate data indicate that the grade of the studied coals range from medium to very low, and the coalification rank ranges from Low Rank A-B for Mesohellenic Trough and Lava (sub-bituminous) to low rank $C$ (lignite) for the rest of the basins (Figure 1b, [2]).

Elementary C, H, N, O and S average data of the studied coal samples are presented in Table 1. Total sulphur values of coals from Northwest and Central Greece range between 0.7 and $1.70 \%$, being classified as low to medium-S coals [12]. Coals from the Lavas basin exhibit the highest average content of $C$ among the lignites of Northwest Greece, whereas those from Amyntaio exhibit the lowest. Additionally, in both the Almyros and Lava basins the xylite-rich lithotype are more carbon-enriched in $\mathrm{C}$ than in the matrix. Plotting the $\mathrm{O} / \mathrm{C}$ and $\mathrm{H} / \mathrm{C}$ on a van Krevelen diagram (Figure 2a) confirms this differentiation among the xylite-rich and matrix lithotypes; additionally, it is evident that Lava coals (falling almost in the sub-bituminous field) are of higher rank than the Ptolemais and Amyntaio, whereas the matrix lithotype of Almyros is the least coalified.
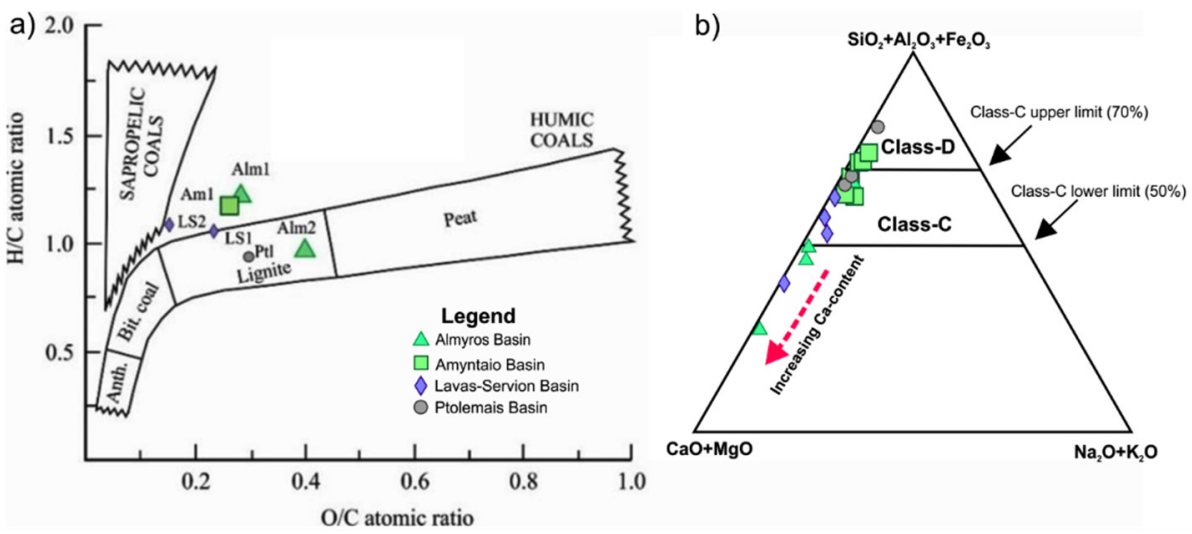

Figure 2. (a) Van Krevelen classification diagram of $\mathrm{O} / \mathrm{C}$ vs. H/C atomic ratios plots for the coal deposits under study; (b) Ternary classification diagram for coal fly ashes.

Table 1. Averaged physicochemical qualitive data of the coal seams from the Mesohellenic Trough (MT; $[13,14])$, Almyros (Alm; [11,15]). Amyntaio (Am; [7,16]; Dimitras (D; [17]). Kastoria (K; [13]), Lavas-Servion (LS; [18]), Prosilio (P; [19,20]) and Ptolemais (Pt; [21,22]).

\begin{tabular}{|c|c|c|c|c|c|c|c|c|c|c|}
\hline & MT1 & $A \operatorname{lm} 1^{a}$ & $A \operatorname{lm} 2^{a}$ & Am1 & D & $\mathbf{K}$ & LS1 $^{b}$ & $\mathrm{LS}^{\mathrm{b}}$ & $\mathbf{P}$ & Ptl \\
\hline Moisture (wt $\%)$ & 9.1 & 50.0 & 52.6 & 54.3 & 50.0 & 48.3 & 46.7 & 21.5 & 42.3 & 44.3 \\
\hline $\operatorname{Ash}(w t \%, d b)$ & 13.5 & 22.0 & 26.4 & 36.0 & 46.4 & & 15.9 & 16.9 & 19.8 & 32.1 \\
\hline $\mathrm{VM}(\mathrm{wt} \%$, daf) & 41.8 & 32.1 & 24.7 & 27.3 & 30.2 & & 30.5 & 41.1 & 34.5 & 55.9 \\
\hline Cfix (wt $\%$, daf $)$ & 48.5 & 23.7 & 20.4 & 17.3 & 19.8 & & 22.7 & 36.0 & 23.1 & 34.2 \\
\hline GCV(kcal/kga.r.) & 5415 & 2600 & 1960 & 1723 & 1850 & 1770 & 2820 & 5560 & 2870 & 2404 \\
\hline $\mathrm{S}_{\text {Total }}(\mathrm{w} \mathrm{t} \%, \mathrm{db})$ & 0.8 & 1.7 & 1.5 & 0.9 & 1.0 & - & 0.7 & 1.1 & 0.7 & 1.1 \\
\hline$C\left(w t^{\%}, d b\right)$ & & 52.6 & 44.8 & 40.8 & & & 58.2 & 63.8 & & 45.1 \\
\hline $\mathrm{H}(\mathrm{wt} \%, \mathrm{db})$ & & 4.3 & 3.2 & 4.2 & & & 5.0 & 5.9 & & 3.0 \\
\hline $\mathrm{N}(\mathrm{wt} \%, \mathrm{db})$ & & 0.5 & 1.1 & 2.8 & & & 1.2 & 0.3 & & 1.0 \\
\hline $\mathrm{O}(\mathrm{wt} \%, \mathrm{db})$ & & 19.3 & 23.9 & 14.2 & & & 18.6 & 12.1 & & 17.9 \\
\hline
\end{tabular}

a: Alm1: west site, Alm2 east site; ${ }^{\text {b: }}$ LS1: matrix lithotype, LS2: xylite-rich lithotype. 


\subsection{Organic Petrographical and Mineralogical Data}

The maceral analysis data of the reviewed coal deposits [11,22] indicate the dominance of huminite group with detrohuminite being the most frequent subgroup. Only in the xylite-rich lythotypes, telohuminite is the major maceral sub-group. Macerals of the liptinite and inertinite groups occur on average with combined values less than $20 \mathrm{vol} \%$. These petrographical features indicate that the almost exclusive accumulation of humic coals originates mostly from herbaceous plants, with minor arboreal contributions (Figure 1b) (e.g., $[23,24])$.

In terms of mineralogical composition, Lavas-Servion coals contain quartz, mica and kaolinite, siderite, pyrite, gypsum, calcite and magnetite $[25,26]$. The lignite of the Ptolemais basin contains silicates in the form of quartz, feldspars and clays, carbonate minerals (calcite, dolomite, aragonite, siderite) and sulphides and sulphates (pyrite, gypsum, anhydrite). In the Amyntaio basin, the major minerals are quartz, kaolinite, siderite, and diaspore, with the secondary occurrence of calcite and gypsum [26]. In the Almyros basin, the main mineralogical assemblages are of quartz, feldspars, gypsum and calcite [11]. The contained minerals reflect primarily the marginal lithologies of the palaeopeatlands, as well as the intense detrital influx during peat formation, which results in the elevated ash yields. Furthermore, the mineral matter type controls the type and the chemistry of the bottom and fly ashes produced during coal combustion.

\subsection{Classification and Geochemical Features of Fly Ashes}

Based on the C-618 classification of fly ashes (ASTM; [27]), fly ashes from Amyntaio and Ptolemais fall into Class-D and Class-C, respectively (Figure $2 b$ ). Nevertheless, the vast majority of NW Greece fly ashes are classified as Class-C. Fly ashes from the Almyros basin are poor in $\mathrm{SiO}_{2}, \mathrm{Al}_{2} \mathrm{O}_{3}$ and $\mathrm{Fe}_{2} \mathrm{O}_{3}$ and rich in $\mathrm{CaO}$ contents, whereas their plots lie closer or within the Class-C field (Figure 2b; [28]).

\subsection{REE and Trace Elements in Coal Samples}

Available data from lignite samples from the Lavas-Servion (NW Greece [29]) and Almyros (C. Greece [11,30]) basins for trace element and Rare Earth Element (REE) concentrations are presented (see Supplementary Material Tables S1 and S2). REE patterns of Lavas-Servion lignites exhibit a high fractionation between light rare earth (LREE) and heavy rare earth (HREE) elements. They also present strong negative Eu anomalies $\left(\mathrm{Eu}_{\mathrm{N}} / \mathrm{Eu}^{*}=1.17-1.31\right)$, negative $\mathrm{Nd}$ anomalies and positive $\mathrm{Tb}$ anomalies. $(\mathrm{La} / \mathrm{Sm})_{\mathrm{N}}$ ratio ranges from 3.33 to 3.59 , whereas $(\mathrm{La} / \mathrm{Yb})_{\mathrm{N}}$ ratio ranges from 7.81 to 8.15 .

Coal samples from the Almyros basin exhibit steep patterns decreasing from LREE to HREE. They also exhibit strong negative $\mathrm{Hf}, \mathrm{Ho}, \mathrm{Tm}$ and $\mathrm{Lu}$ anomalies with positive Sm, $\mathrm{Dy}, \mathrm{Er}$ and $\mathrm{Yb}$ anomalies. Eu $\mathrm{N}_{\mathrm{N}} / \mathrm{Eu}^{*}$ ratio is extensively variable $(0.88$ to 1.31$)$. (La/Sm $)_{\mathrm{N}}$ and $(\mathrm{La} / \mathrm{Yb})_{\mathrm{N}}$ ratios range from 2.50 to 3.33 and 5.43 to 10.87, respectively (Figure 3a). Lignites from the Lavas-Servion basin exhibit higher REE contents compared to those of Almyros basin.

Coal occurrences from Lavas-Servion basin exhibit a wide range of $\mathrm{V}$ (V:30.40-95.10 ppm) and $\mathrm{Ba}$ values (Ba: $46.90-101.80 \mathrm{ppm}$ ), whereas $\mathrm{Zn}$ contents are quite high ( $\mathrm{Zn}$ : $56.90-88.50 \mathrm{ppm})$. Coal occurrences from Almyros basin display a wide range of $\mathrm{Cr}$ and $\mathrm{V}$ contents (Cr: $57.20-136.00$ ppm; V: 60.40-134.00 ppm). In addition, Ba and Sr values are quite high ranging from 123.20 to $156.50 \mathrm{ppm}$ and 142.80 to $194.20 \mathrm{ppm}$.

Analysis of the data presents sub-parallel patterns of multitrace elements in the LavasServion and Almyros basins (Figure 3b), characterized by strong positive $\mathrm{Th}, \mathrm{Pb}$ and $\mathrm{Ta}$ anomalies. In addition, they exhibit slightly positive $\mathrm{P}$ and Sm anomalies and slightly negative $\mathrm{Zr}$ anomalies. Sr presents negative anomalies in Lavas-Servion lignites and positive anomalies in Almyros lignites. 

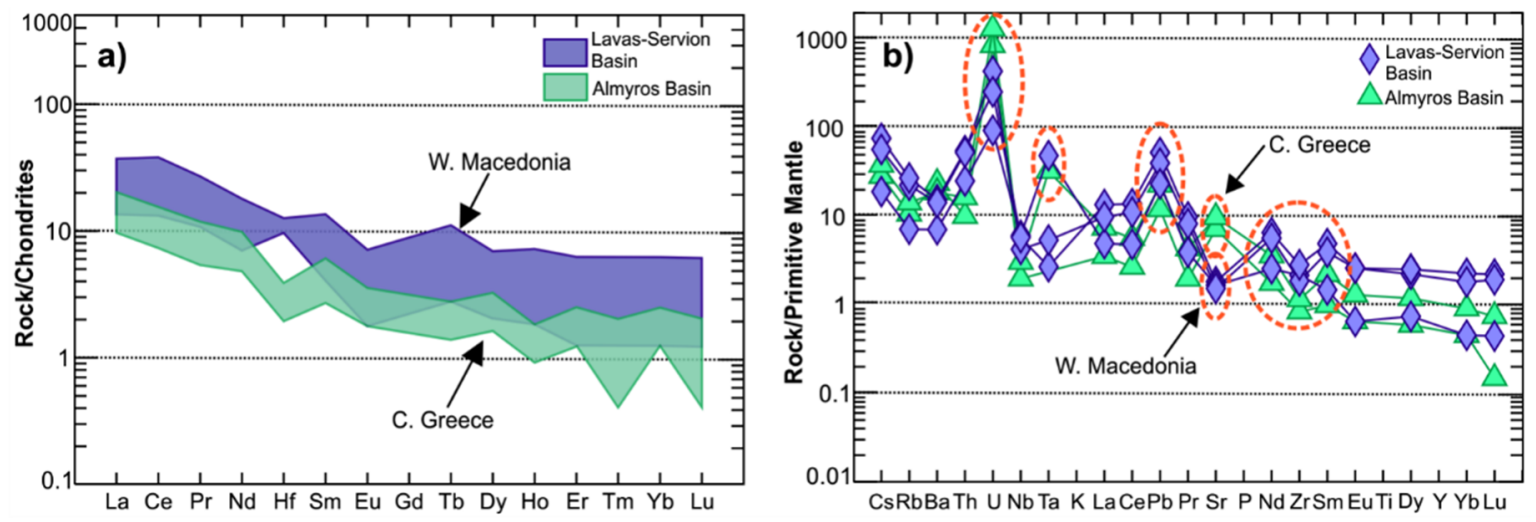

Figure 3. (a) Chondrite normalized-REE patterns (Normalization factors after McDonough and Sun, [31]) from coal samples from Lavas-Servion and Almyros basins (data from Supplementary Materials Table S2), (b) Primitive mantle-normalized patterns for samples from Lavas-Servion and Almyros basins (Normalization factors after McDonough and Sun, [31]).

The occurrence of significant detrital mineral components such as monazite, allanite, zircon and xenotime is a major factor that controls the REE-enrichment in coal samples [32,33]. Monazite is usually associated with high REE values and negative Eu anomalies. Lavas-Servion coal exhibits quite elevated REE contents and negative Eu anomalies. Th values are positively correlated with IREE contents (IREE-Th: 17.33-2.00 ppm; 49.85-4.40 ppm; 40.13-4.20 ppm). An alternative hypothesis for the strong Eu anomalies can be associated with the occurrence of plagioclase grains. The positive $\mathrm{Nd}$ anomalies of Lavas- Servion coal also support the presence of REE-bearing monazite, which is an Nd-bearing mineral. Sr anomalies are associated with the occurrence (positive anomaly) or the absence (negative anomaly) of plagioclase grains, indicating that fly ashes from the Almyros basin are plagioclase-bearing, whereas those from the Lavas-Servion basin lack plagioclase grains.

Uranium exhibits strong positive anomalies in the multitrace element patterns of Figure 3a. The occurrence of $\mathrm{U}$ in coal is usually associated with the amount of organic matter, and occasionally with the presence of U-bearing minerals [34-36]. Although detailed studies of Greek coals and related ashes regarding U affinity are limited, evidence for organic affiliation are provided for Megalopolis lignite and a bituminous coal layer in the Parnassos area $[37,38]$.

\subsection{REE and Trace Elements in Fly Ashes}

Class-C fly ashes usually tend to be more abundant in REE, compared to the other types, due to the substitution of $\mathrm{Ca}^{+2}$ and $\mathrm{Fe}^{+3}$ by trivalent LREE and HREE, respectively, being highly comparable with fly ashes derived from the Powder River Basin and Jungar coals [32]. Moreover, there is a significant relationship between the Fe-oxides components in fly ash, formed from glass devitrification during coal combustion and the REE abundance [32,39-41].

These results can explain the higher REE Chondrite Normalized patterns of coal fly ash samples from the Lavas-Servion basin (Class-C), compared to those of their parent coal (Figure 4). The REE-bearing minerals of the coal fly ash are usually hosted within the Si-Al glass matrix, which offers them a low leaching efficiency [36,42]; a similar pattern has been reported for coals in Greece regarding the behaviour of REE in laboratory produced ashes [38], as well as for selective trace element enrichments (e.g., Th, Yb) from lignite occurrences in the region of Lofoi (Florina basin) [43]. The total REE and Th in coal fly ash samples range from 164.1 to $418.8 \mathrm{ppm}$ and 6.2 to 10.7 , respectively, whereas Ce is strongly enriched. This is indicative of the presence of monazite within the coal fly ash samples, whereas the occurrence of REE-bearing allanite cannot be excluded. 


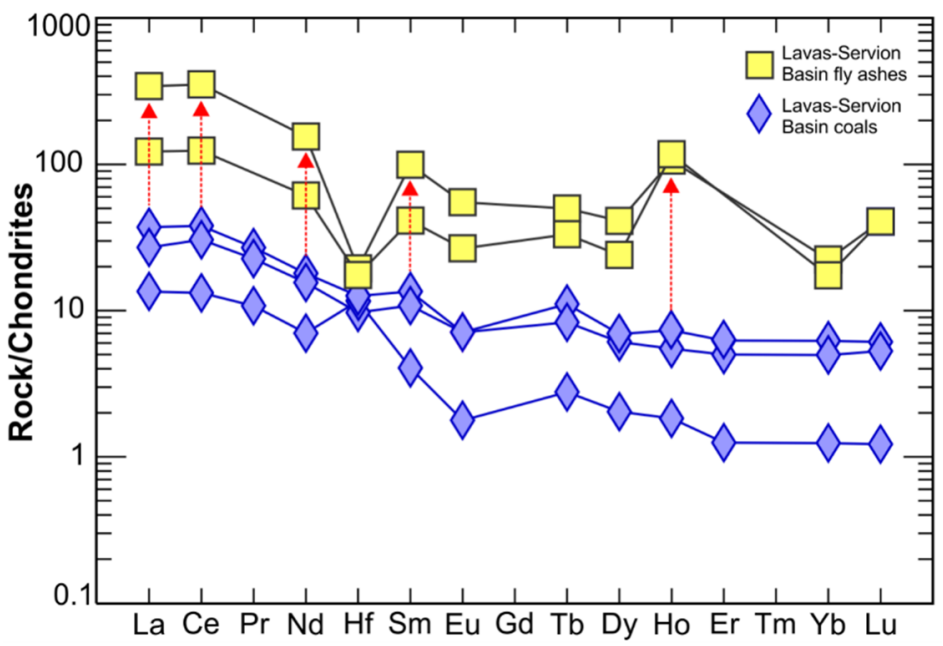

Figure 4. Chondrite normalized-REE patterns (Normalization factors from McDonough and Sun, [31]) from coal samples from Lavas-Servion and Ptolemais basins.

\section{Conclusions}

Physicochemical properties of coal seams derived from the regions of northwest and central Greece are investigated against the coalification grade of the respective coals. Both areas are characterized by the predominance of huminite group minerals. Inorganic mineral components include quartz, feldspars, sulphides, sulphates, micas, carbonates and Fe-oxides in various and unequal amounts between the different basins. Coal occurrences from NW Greece exhibit higher Rare Earth Element (REE) contents compared to those of Central Greece. This can be attributed to the occurrence of allanites, Fe-oxides and especially monazite, confirmed by the strong negative Eu anomalies and the higher Th values in samples from the Lavas-Servion basin. According to the ASTM classification, coal seams are mainly classified as $\mathrm{C}$-Class $\mathrm{CaO}$ rich coals. In terms of coalification, the reported coals range from sub-bituminous in Mesohellenic Trough, Lava and Prosilio to lignites in Ptolemais, Amyntaio, the less mature being in Almyros.

Supplementary Materials: The following supporting information can be downloaded at: https: //www.mdpi.com/article/10.3390/materproc2021005103/s1, Table S1: Averaged Trace element content for the xylite-rich and matrix lignite deposits of the Almyros basin $[11,30])$ and the LavasServion basin [29]; Table S2: Averaged Rare Earth Element (REE) content (ppm) for the xylite-rich and matrix lignite deposits of the Almyros basin [1,2] and the Lavas-Servion basin [3].

Author Contributions: Conceptualization, N.K., S.K., P.K., C.K. and A.B.; methodology, N.K., S.K., P.K., C.K. and A.B.; software, S.K., P.K., A.B. and C.K.; validation, N.K., S.K., P.K., A.B., C.K., P.T. and D.K.; formal analysis, N.K., S.K., P.K., A.B., C.K., P.T. and D.K.; investigation, N.K., S.K., P.K., A.B., C.K., P.T. and D.K.; data curation, S.K., P.K., A.B. and C.K.; writing-original draft preparation, N.K., S.K., P.K., A.B., C.K., P.T. and D.K.; writing-review and editing, N.K., S.K., P.K., A.B., C.K., P.T. and D.K.; visualization, N.K., P.K., C.K., A.B. and P.T.; supervision, N.K., S.K. and P.K.; project administration, N.K., S.K. and P.K. All authors have read and agreed to the published version of the manuscript.

Funding: This research received no external funding.

Institutional Review Board Statement: Not applicable.

Informed Consent Statement: Not applicable.

Data Availability Statement: Data is contained within the article or Supplementary Material.

Acknowledgments: We would like to acknowledge the Editor for handling the overall manuscript processing. In addition, Hellenic Survey of Geology and Mineral Exploration (HSGME), as well as the Greek Public Power Corporation (PPC) are likely acknowledged for providing partly published and unpublished data. 
Conflicts of Interest: The authors declare no conflict of interest.

\section{References}

1. Merzartasoglou, D.; Stampolis, K.; Koutroumpousis, A.; Perellis, A. The Greek Energy Sector Annual Report 2020 (in Greek); Institute of Energy for SE Europe (IENE): Athens, Greece, 2020; p. 201.

2. Economic Commission for Europe. International Classification of In-Seam Coals; United Nations: Geneva, Switzerland, 1998.

3. Brunn, J. Contribution à 1 'étude géologique du Pinde septentrional et d' une partie de la Macedoine Occidentale. Ann. Geol. Pays Hellén. 1956, 7, 1-158.

4. Aubouin, J. Contribution à l 'étude géologique de la Gréce septantrionale: Les confins de l' Epire et de la Thessalie. Ann. Geol. Pays Hellén. 1959, 10, 1-483.

5. Papanikolaou, D.; Lekkas, E.; Mariolakos, E.; Mirkou, P. Contribution to the geodynamic evolution of Mesohellenic Trough. Bull. Geol. Soc. Greece. 1986, 20, 17-36.

6. Vamvaka, A. Geometry of Deformation and Kinematic Analysis in Mesohellenic Trough; Aristotle University of Thessaloniki: Thessaloniki, Greece, 2009.

7. Koukouzas, K.; Kotis, T.; Ploumidis, M.; Metaxas, A. Geological and Ore Study of the Lignite of the Anargyri-Amyntaio Lignite Deposit. Ore Geological Studies; Institute of Geology and Mineral Exploration of Greece: Athens, Greece, 1979.

8. Koukouzas, C. Geological Map of Greece, Ptolemais sheet, Scale: 1:50.000; IGME: Athens, Greece, 1997.

9. Anastopoulos, I.; Koukouzas, K. Prosilio-Trigoniko Lignite Basin (Kozani); IGME: Athens, Greece, 1969; pp. 1-24.

10. Papanikolaou, K. The contribution of biomarkers and lignite ore petrography in the study of the depositional environment of coal deposits from Vevi-Florina, Labas-Servion-Kozani, Moschopotamos-Pieria and Palaiochorio-Kalavrita basins. In Proceedings of the first Conference of the committee of Economical geology of EGE Mineral Resources and Environment in Western Macedonia, Kozani, Greece, 12-13 February 2000; pp. 351-364.

11. Bouzinos, A. The Lignite Deposit of Almyros (Magnisias): Genesis, Evolution and Potential Exploitation; University of Patras: Patras, Greece, 2004.

12. Chou, C.L. Sulfur in coals: A review of geochemistry and origins. Int. J. Coal Geol. 2012, 100, 1-13. [CrossRef]

13. Varvarousis, C.; Metaxas, A.; Kotis, T.; Ploumidis, M.; Vretos, K. Research and Evaluation Lignite Basin Deposits Kozani-Servia, Sarantaporo Kastoria. Kastoria Basin; IGME: Athens, Greece, 2000; p. 45.

14. Kotis, T.; Metaxas, A. Report on the Results of Geological-Ore Deposits Recognition for Coal of Asprokklisia Community of Trikala prefecture; Department of Energy Raw Materials (ADHD), Institute of Geology and Mineral Exploration (IGME): Athens, Greece, $1988 ;$ p. 11.

15. Giakkoupis, I.; Arapogiannis, E. Lignite of the Almyros Deposit: Geological-Ore Studies; IGME: Athens, Greece, $1997 ;$ p. 175.

16. Koukouzas, N. Quality characteristics of Coals (Greece); Tsotras Publishing: Athens, Greece, 2019; p. 1022.

17. Papaspyros, A. Ore Geological Research of the Lignite Basin of Dimitras Karpero Region (Grevena); Institute of Geology and Mineral Exploration of Greece (IGME), Department of Energy Resources: Athens, Greece, 1993; pp. 9, 46.

18. Karageorgiou, E. Lignite Basins of Kozani, Servia, Sarantaporos and Elassona; Subsurface Investigation Agency, Institute of Geology and Mineral Exploration (IGME): Athens, Greece, 1951; p. 31.

19. Antoniadis, P. The lignite deposit of Prosilio (Kozani). Min.-Metall. Ann. 1985, 60.

20. Antoniadis, P. Lignite occurrence in parts of the Prosilio-Trigoniko basin (Kozani). Bull. Hell. Geol. Soc. 1986, 18, 113-130.

21. Koukouzas, K.; Kotis, T.; Ploumidis, M.; Metaxas, A. The Lignite Deposit of Komninon Ptolemais Region. Special Studies and Researches; Institute of Geology and Mineral Exploration of Greece: Athens, Greece, 1984; p. 103.

22. Papanicolaou, C.; Kotis, T.; Kokkinakis, P.; Karageorgiou, D.; Brettos, K.; Demetriou, D. Research and Study of Selected Organogenic Sediments for Uses Other than Power Generation (in Greek); IGME: Athens, Greece, 2006; p. 279.

23. Christanis, K. Coal facies studies in Greece. Int. J. Coal Geol. 2004, 58, 99-106. [CrossRef]

24. Kalaitzidis, S.; Bouzinos, A.; Papazisimou, S.; Christanis, K. A short-term establishment of forest fen habitat during Pliocene lignite formation in the Ptolemais Basin, NW Macedonia, Greece. Int. J. Coal Geol. 2004, 57, 243-263. [CrossRef]

25. Foscolos, A.; Goodarzi, F.; Koukouzas, C.; Hatziyannis, G. Reconnaissance study of mineral matter and trace elements in Greek lignite's. Chem. Geol. 1989, 76, 107-130. [CrossRef]

26. Koukouzas, K.; Foscolos, A.; Hatziyannis, G. Trace Element Study of the Greek Coals; Public Power Corporation of Greece Ptolemais: Athens, Greece, 1985.

27. ASTM. Concrete and aggregates. In Annual Book of ASTM Standards; American Society for Testing and Materials: Philadelphia, PA, USA, 1996; Volume 4.02, p. 293.

28. Koukouzas, N.; Hämäläinen, J.; Papanikolaou, D.; Tourunen, A.; Jantti, T. Mineralogical and Chemical Composition of Cfb Fly Ash Derived From Co-Combustion of Xylite and Biomass. Bull. Geol. Soc. Greece 2007, 40, 859-871. [CrossRef]

29. Georgakopoulos, A. Trace elements in the lava xylite/lignite deposit, Servia basin, Northern Greece. Energy Sources 2001, 23, 143-156. [CrossRef]

30. Bouzinos, A.; Christanis, K.; Valsami-Jones, E. Geochemical study of the Almyros (N. Magnesia) lignite deposit. (in Greek). In Proceedings of the second conference of the Economic Geology, Mineralogy and Geochemistry committee of the Geological Society of Greece, Thessaloniki, Greece, 7-9 October 2005; pp. 269-278.

31. McDonough, W.F.; Sun, S.S. The composition of the Earth. Chem. Geol. 1995, 120, 223-253. [CrossRef] 
32. Kolker, A.; Scott, C.; Hower, J.C.; Vazquez, J.A.; Lopano, C.L.; Dai, S. Distribution of rare earth elements in coal combustion fly ash, determined by SHRIMP-RG ion microprobe. Int. J. Coal Geol. 2017, 184, 1-10. [CrossRef]

33. Finkelman, R.B. Modes of Occurrence of Trace Elements in Coal. Ph.D. Thesis, University of Maryland, College Park, MD, USA, 1981; p. 301.

34. Dai, S.; Wang, P.; Ward, C.R.; Tang, Y.; Song, X.; Jiang, J. Elemental and mineralogical anomalies in the coal-hosted Ge ore deposit of Lincang, Yunnan, southwestern China: Key role of $\mathrm{N}_{2}-\mathrm{CO}_{2}$-mixed hydrothermal solutions. Int. J. Coal Geol. 2015, 152, 19-46. [CrossRef]

35. Liu, J.; Yang, Z.; Yan, X.; Ji, D.; Yang, Y.; Hu, L. Modes of occurrence of highly-elevated trace elements in superhigh-organic-sulfur coals. Fuel 2015, 156, 190-197. [CrossRef]

36. Yang, Z.; Li, Y.; Lou, Q.; Liu, D.; Ning, Y.; Yang, S.; Tang, Y.; Zhang, Y.; Tang, Z.; Wang, X. Release of uranium and other trace elements from coal ash by $\left(\mathrm{NH}_{4}\right)_{2} \mathrm{SO}_{4}$ activation of amorphous phase. Fuel 2019, 239, 774-785. [CrossRef]

37. Siavalas, G.; Linou, M.; Chatziapostolou, A.; Kalaitzidis, S.; Papaefthymiou, H.; Christanis, K. Palaeoenvironment of Seam I in the Marathousa Lignite Mine, Megalopolis Basin (Southern Greece). Int. J. Coal Geol. 2009, 78, 233-248. [CrossRef]

38. Kalaitzidis, S.; Siavalas, G.; Skarpelis, N.; Araujo, C.V.; Christanis, K. Late Cretaceous coal overlying karstic bauxite deposits in the Parnassus-Ghiona unit, Central Greece: Coal characteristics and depositional environment. Int. J. Coal Geol. 2010, 81, 211-226. [CrossRef]

39. Waanders, F.B.; Vinken, E.; Mans, A.; Mulaba-Bafubiandi, A.F. Iron Minerals in Coal, Weathered Coal and Coal Ash-SEM and Mössbauer Results. Hyperfine Interact. 2003, 148, 21-29. [CrossRef]

40. Zeng, T.; Helble, J.J.; Bool, L.E.; Sarofim, A.F. Iron transformations during combustion of Pittsburgh no. 8 coal. Fuel 2009, 88 , 566-572. [CrossRef]

41. Yang, J.; Zhao, Y.; Zyryanov, V.; Zhang, J.; Zheng, C. Physical-chemical characteristics and elements enrichment of magnetospheres from coal fly ashes. Fuel 2014, 135, 15-26. [CrossRef]

42. Hower, J.C.; Qian, D.; Briot, N.J.; Henke, K.R.; Hood, M.M.; Taggart, R.K.; Hsu-Kim, H. Rare earth element associations in the Kentucky State University stoker ash. Int. J. Coal Geol. 2018, 189, 75-82. [CrossRef]

43. Pentari, D.; Foscolos, A.E.; Perdikatsis, V. Trace Elements inthe Lignite-bearing Area of Lofoi, Florina Basin, Western Greek Macedonia, Greece. Energy Sources 2007, 30, 316-324. [CrossRef] 